\title{
Tapping the Potential of Large Scale Solar PV System in Sabah: The Feasibility Analysis
}

\author{
Maryam Huda, Keiichi Okajima, Kengo Suzuki \\ Risk Engineering Department, System and Information Engineering, University of Tsukuba, Ibaraki, Japan \\ Email: m.huda.ap@gmail.com
}

How to cite this paper: Huda, M., Okajima, K. and Suzuki, K. (2017) Tapping the Potential of Large Scale Solar PV System in Sabah: The Feasibility Analysis. Energy and Power Engineering, 9, 108-118. https://doi.org/10.4236/epe.2017.92009

Received: December 13, 2016

Accepted: February 24, 2017

Published: February 27, 2017

Copyright @ 2017 by authors and Scientific Research Publishing Inc. This work is licensed under the Creative Commons Attribution International License (CC BY 4.0).

http://creativecommons.org/licenses/by/4.0/ (c) (i) Open Access

\begin{abstract}
As a developing country with the rapid growth of economic and population like Malaysia, energy and electricity play a critical role towards sustaining and supporting the development of the nation. However, like many countries across the world, Malaysia is facing challenges in reducing the carbon footprint while attending the expanding growth. In the Eleventh Malaysia Plan, Malaysia has pledged to renew and increase its commitment to the environment and long-term sustainability by adopting green growth initiatives. According to the plan, one of the approaches towards pursuing green growth is by undertaking the sustainable consumption and production concept that promotes economic growth without compromising the environment. One of the strategies is to focus on promoting renewable energy sources as well as boosting up the development of the systems. The last decade has seen a growing trend towards renewable energy in Malaysia, particular in solar photovoltaic applications in recent years. This paper will investigate the potentials of installing $5 \mathrm{MW}$ solar PV plants in the state of Sabah according to feed in tariff incentives and its financial and environmental assessment in order to promote large scale solar PV in Malaysia. This paper calculates the economic viability through IRR and simple payback indicators and the environmental impact through $\mathrm{CO}_{2}$ emission reduction indicator for the proposed $5 \mathrm{MW}$ plant.
\end{abstract}

\section{Keywords}

Large Scale Solar PV, Feed in Tariff, Renewable Energy, $\mathrm{CO}_{2}$ Emission Sabah Malaysia

\section{Introduction}

Malaysia is a country made up of Peninsular Malaysia and the states of Sabah and Sarawak on the island of Borneo. The population in this country has reached 29.72 million today, with $80 \%$ of the total 23.5 million people live in Pe- 
ninsular Malaysia, 3.5 billion in Sabah and 2.6 billion in Sarawak. Energy has been the most important catalyst towards the rapid growth of Malaysia's population as well as the economy. The fast pace developments, as well as the rising living standards and greater income per capita, have stimulated a tremendous energy demand. However, the high consumption of fossil fuel resources is known to give more damage than good to the environment. Therefore there has been a trend in developing countries towards shifting to renewable energy resources in order to mitigate the impact on the environment. Malaysia is no exception in this commitment in the energy balance towards a more sustainable development. Malaysia has promised to continue pursuing green growth, in terms of policy and regulatory framework, and green technology investment. According to the plan, Malaysia is committed to continuing the required capacities, capabilities and skills towards supporting the green growth development including the renewable energy initiatives [1] [2].

\subsection{Malaysian Energy Supply}

Malaysia is known for a diversified primary energy resources country. The primary energy supply includes oil, natural gas, coal and a variety of renewable energy resources mainly hydro and solar power and biomass. However from a total of 141,266 GWh (2013) fossil fuels call for $90 \%$ of Malaysia electricity generation mix. [3] The dependency on fossil fuels due to the cheaper option as well as rising electricity demand is unavoidable. It is notable that the fuel consumption in Malaysia has dropped in 1997 due to the economic and financial crisis which affected domestic consumption and investment. However in April 2010, along with the Fifth Fuel Policy, the Malaysian government approved the National Renewable Energy Policy and Action Plan to promote further development in the renewable energy (RE) sector [1] [2].

\subsection{Sabah Generation Mix and Electricity Demand}

Sabah is a state in Malaysia located on the island of Borneo next to Sarawak as shown in Figure 1. With population of more than 3.5 million. Sabah is known for its maturing economy of local tourism and natural produces such timber and palm oil. The growing economy of Sabah has driven an increasing energy as well as electricity demand. However, Sabah is now facing a dilemma where high occurrence of power shortage is experienced throughout the state. As of 2015 Sabah total generation mix is primarily fuelled by gas $76 \%$, followed by diesel/MFO $15 \%$, hydro $6 \%$ and biomass/biogas 3\% (Figure 2). As shown in Figure 3, apart from the stagnant growth in 2010, a contraction caused by the global financial crisis in 2008 onward which slowed down the manufacturing sector, Sabah electricity demand is increasing at over $7 \%$ per year and forecasted to continue growing alongside the rise of GDP. However, much of Sabah's existing capacity is in the form of aging, expensive, and unstable diesel plants. The east coast of Sabah, almost wholly relies on these diesel plants (Figure 4) and the high occurrence of outages may affect the economy as well as the utility company financially. In 


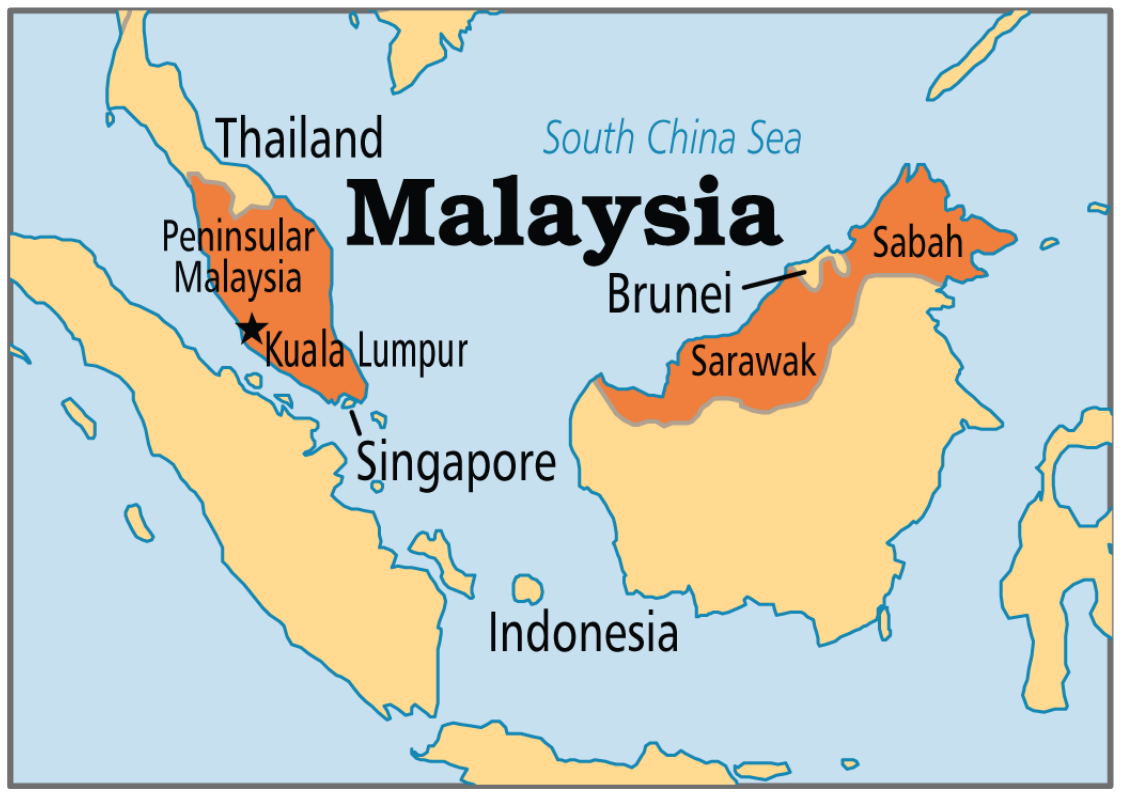

Figure 1. Map of Malaysia.

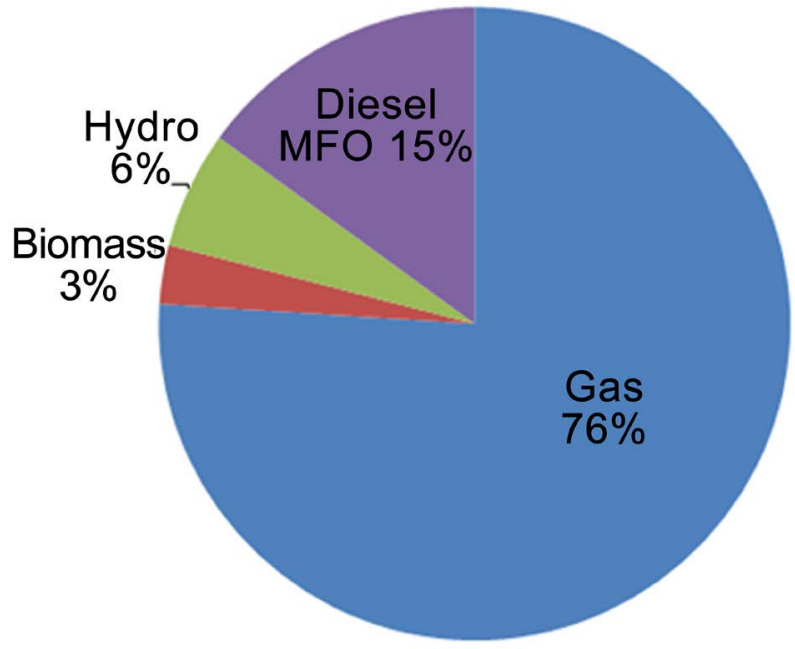

Figure 2. Sabah generation mix in 2015 [4].

order to meet the growing demand, Sabah's electric utility-Sabah Electricity Sdn. Bhd (SESB) is planning to expand the generation capacity over the next 10 years, and phases out some MFO plants from the overall mix. Total generation from diesel by SESB in 2014 accounts for of 488 GWh and SESB is still dealing with the issue of lack of generation capacity to meet the growth in electricity demand. Sabah electricity demand is forecasted to grow at a rate of $5.8 \%$ through out the coming years as shown in Figure 5 [4].

\subsection{Feed-in Tariff Policy in Malaysia}

FiT mechanism was introduced by the Malaysian government under National Renewable Energy Policy and Action Plan (2010) and is currently carried out by 


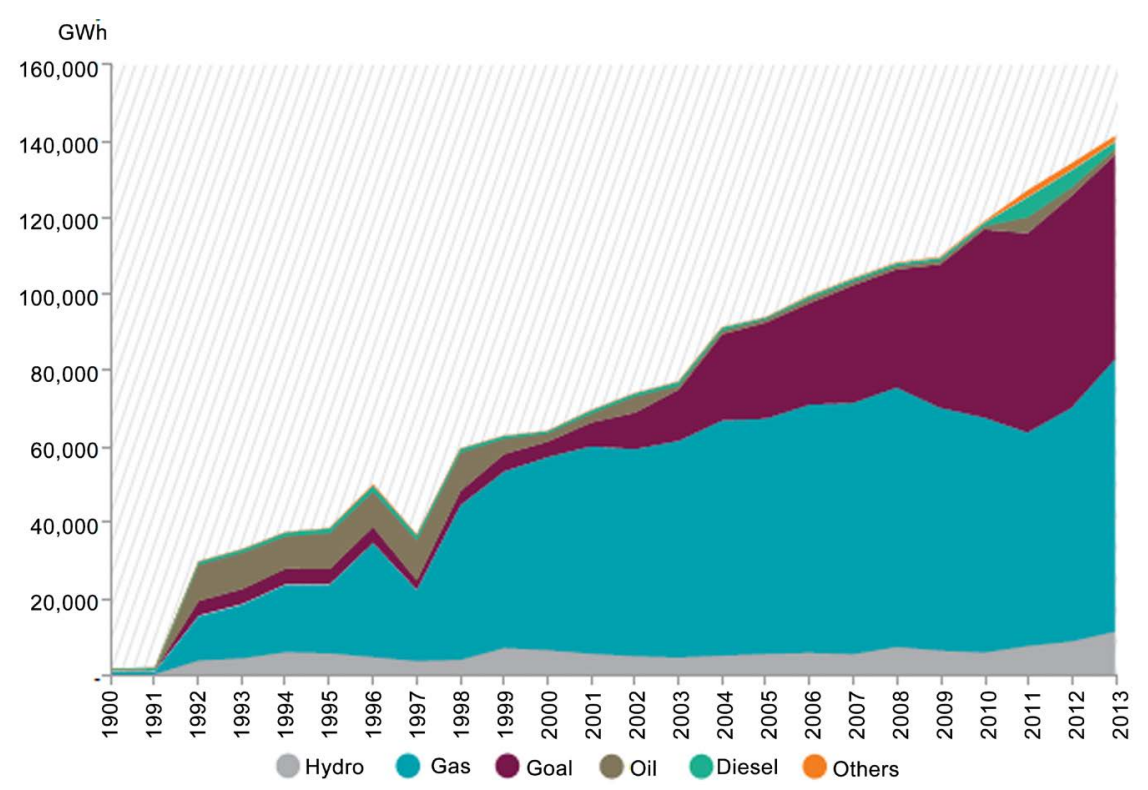

Figure 3. Malaysia electricity generation mix by fuel type (Suruhanjaya Tenaga).

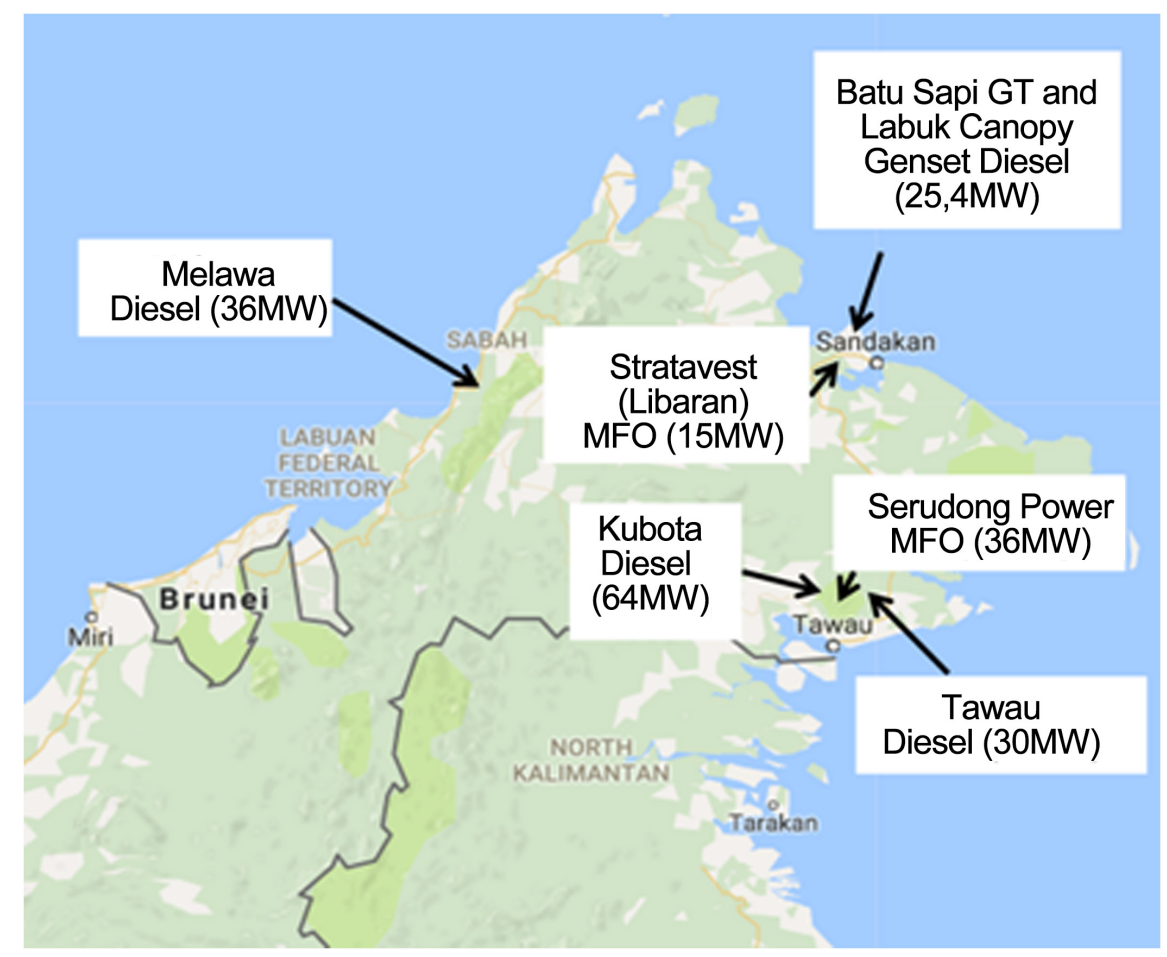

Figure 4. Existing diesel and MFO power plants in Sabah [4].

Sustainable Energy Development Authority, Malaysia (SEDA Malaysia) under the authority of by Ministry of Energy, Green Technology and Water (KeTTHA). FiT is a policy described as a mechanism that allows RE producers to generate electricity from any RE resources by offering long-term contracts for the generated power to be sold to power utilities at a fixed premium price. The objectives of FiT mechanism are

- To increase RE contribution in the national power generation mix; 


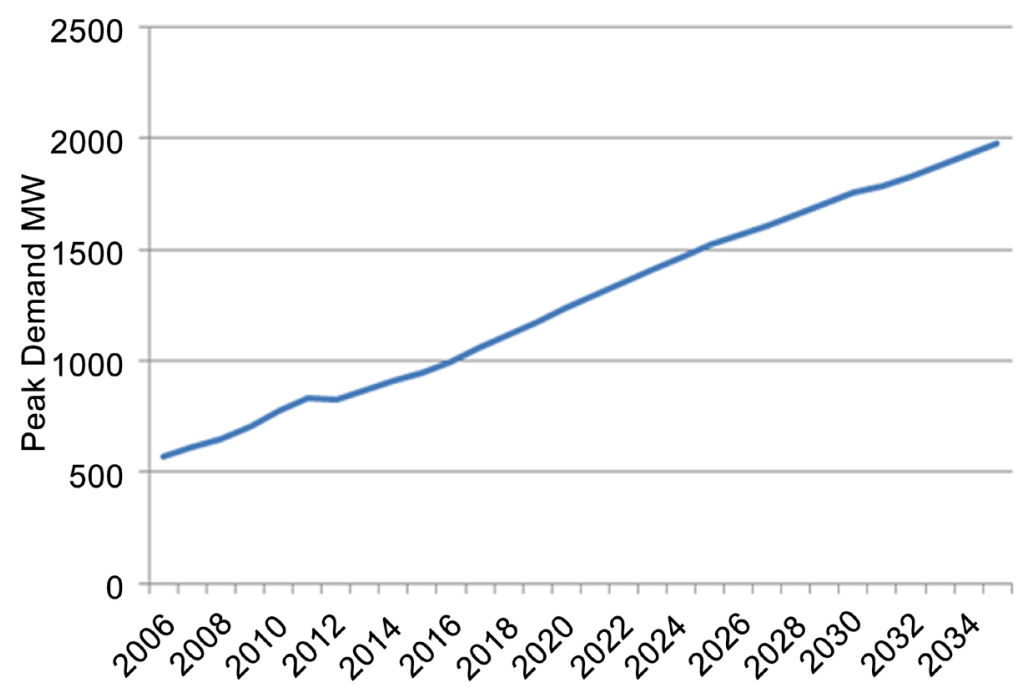

Figure 5. Sabah Electricity demand forecast [4].

Table 1. Feed in Tariff rate for Solar PV (Non-Individual) [6].

\begin{tabular}{cc}
\hline Installed Capacity & Fit Rates (RM per KWh) \\
\hline Up to and including $4 \mathrm{~kW}$ & 0.8249 \\
above $4 \mathrm{~kW}$ and up to and including $24 \mathrm{~kW}$ & 0.8048 \\
above $24 \mathrm{~kW}$ and up to and including $72 \mathrm{~kW}$ & 0.6139 \\
above $72 \mathrm{~kW}$ and up to and including $1 \mathrm{MW}$ & 0.593 \\
above $1 \mathrm{MW}$ and up to $10 \mathrm{MW}$ & 0.4651 \\
above $10 \mathrm{MW}$ and up to and including $30 \mathrm{MW}$ & 0.4162 \\
\hline
\end{tabular}

- To facilitate the growth of the RE industry;

- To ensure reasonable RE generation mix;

- To conserve the environment for future

- To enhance awareness on the role and importance of RE [5] [6].

The FiT rate for solar photovoltaic for 21 years from commencement date is shown in Table 1.

\section{Objective}

According to Malaysia Eleventh Plan, one of the approaches towards pursuing green growth is by undertaking the sustainable consumption and production concept that promotes economic growth without compromising the environment. One of the strategies is to focus on promoting renewable energy sources as well as boosting up the development of the systems. Prime Minister YAB Dato' Sri MohdNajibTun Abdul Razak announced that Malaysia would voluntarily reduce its emissions intensity of GDP by up to $40 \%$ based on 2005 levels, by 2020. [1] [2] In line with the target, this study is to investigate the potentials of one of the low-carbon measures in term or integration of renewable energy in Malaysia's electricity generation specifically solar photovoltaic technology. Due to the advantage of its location in the tropical region, there is a strong pro- 
spective to install large scale solar PV throughout the country [9]. This paper will investigate the potential available for large scare solar PV installation in Sabah, and the amount of $\mathrm{CO}_{2}$ mitigated by replacing the diesel power plants with 5 MW solar PV plants. Installation of large scale solar PV plants are may contribute to the reduction of the total amount of $\mathrm{CO}_{2}$ emission in Malaysia.

\section{Methodology}

This analysis consists of 3 main elements;

- Estimation of the energy production potential,

- Financial feasibility in terms of simple payback and IRR from the proposed $5 \mathrm{MW}$ plant,

- Assessment of the anticipated reductions in $\mathrm{CO}_{2}$ emissions if the plant were constructed

To estimate the energy production and financial feasibility of the hypothetical PV plant, this study uses RETScreen software. RETScreen was created in 1996 by Natural Resources Canada's Canmet Energy Research Center to provide lowcost preliminary assessments of RE projects. Independent reviews of RETScreen software validate its results all reporting RETScreen calculations to be within $0 \%$ - $6 \%$ of actual energy production [7]. Solar irradiation in the area are taken from the NASA website of Surface meteorology and solar energy [8]. To estimate the amount of carbon dioxide emissions avoided, the RETScreen predictions of the energy production of the PV plant are used to estimate the amount by which energy production from all the diesel plants in Sabah could decrease over the period of 10 years. Annual emissions data obtained from the power plant are used to estimate the air pollutant emissions avoided when a portion of the diesel plants' energy production is replaced with PV energy based on 2 scenarios:

Scenario 1 (S1): proposed one 5MW solar PV plant for each diesel plant in Sabah.

Scenario 2 (S2): proposed 5MW solar PV plants to cover for 2025 electricity production from diesel.

\section{The Proposed 5 MW Plant}

The proposed solar PV power plant-which is a grid-connected system with 5 MW installed capacity-consists of 15,625 unit one axis tracking modules with a total area of $30,506 \mathrm{~m}^{2}$. The slope and azimuth angle was taken as zero for all the studied sites. Table 2 shows the module's specifications. The financial assumptions for this plant are presented in Table 3. The initial cost for the plant is assumed as MYR 40 million [10] with operation and maintenance cost MYR 100,000 while the inflation rate is taken as $3 \%$.

\section{Results and Discussion}

\subsection{Electricity Production}

The annual amount of electricity generation, which is the amount of equivalent DC electrical energy actually delivered by the proposed grid-connected 5 MW 
Table 2. PV Module Specifications.

\begin{tabular}{cc}
\hline Item & Specification \\
\hline Manufacturer & JA Solar \\
PV module type & Poly-Si \\
Module number & JAP672-320/4BB \\
Module efficiency & $16.51 \%$ \\
Dimensions & $1956 \mathrm{~mm} \times 001 \mathrm{~mm} \times 45 \mathrm{~mm}$ \\
Maximum System Voltage & DC1000V \\
Operating Temperature & $-40^{\circ} \mathrm{C}-85^{\circ} \mathrm{C}$ \\
Maximum Series Fuse & $15 \mathrm{~A}$ \\
\hline
\end{tabular}

Table 3. Financial Assumptions.

\begin{tabular}{cc}
\hline Initial cost & MYR 40,000,000 \\
O \& M cost & MYR 100,000 \\
Feed-in Tariff & MYR 465/MWh \\
Project life & 21 years \\
Inflation rate & $3 \%$ \\
\hline
\end{tabular}

solar PV power plant to the utility, was calculated for all the 8 locations, with all plants located within $1.5 \mathrm{~km}$ radius from main substation or grid to minimize transmission and distribution loss. The results are exhibited in Figure 4. The highest production was obtained from Tawau, Tenom, Beufort, and Papar power plants. Their production was close to each other, and equal to $8.876,8.851$, and 8.852 and $8.857 \mathrm{GWh} /$ year respectively. The average electricity production for the proposed 5MW power plant is projected to be 8377 MWh annually available for export in Sabah. Figure 6 shows Sabah generation forecast of diesel power plants in ten years whereby the diesel power plants will slowly be reduced and replaced with electricity generation from natural gas power plants. This forecast is plotted together with the two proposed scenarios for large scale solar PV power plants.

As illustrated in Figure 7, in Scenario 1, a single power plant in Sabah would be able to export at least 7.5 GWh of electricity annually. Sabah utility company forecasted by 2025 total of $194.94 \mathrm{GWh}$ of diesel generation is still needed to accommodate the demand and will be retiring several diesel and MFO power plants by then [4]. Therefore in comparison with this forecast with average of $8377 \mathrm{MWh}$ of electricity production annually, approximately 24 of solar PV plants are needed to cover for electricity production from diesel in 2025 as for Scenario 2 .

\subsection{Financial Analysis}

Retscreen software calculated the Pre-tax IRR (internal rate of return) and simple payback. The internal rate of return IRR is the discount rate that causes the Net Present Value (NPV) of the project to be zero. The pre-tax IRR was calculated using pre-tax cash flows, while the after-tax IRR was calculated using the after tax cash flows. In this paper, we only calculate the pre-tax IRR and the sim- 


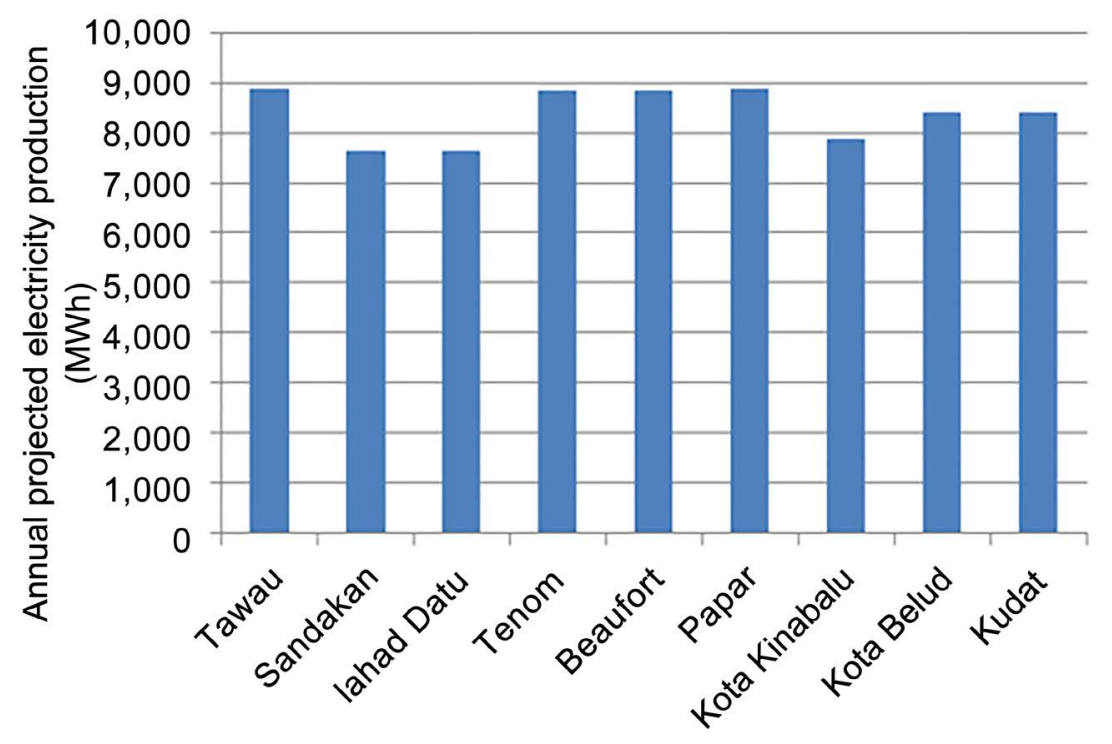

Figure 6. 5MW solar PV plant potentials in Sabah.

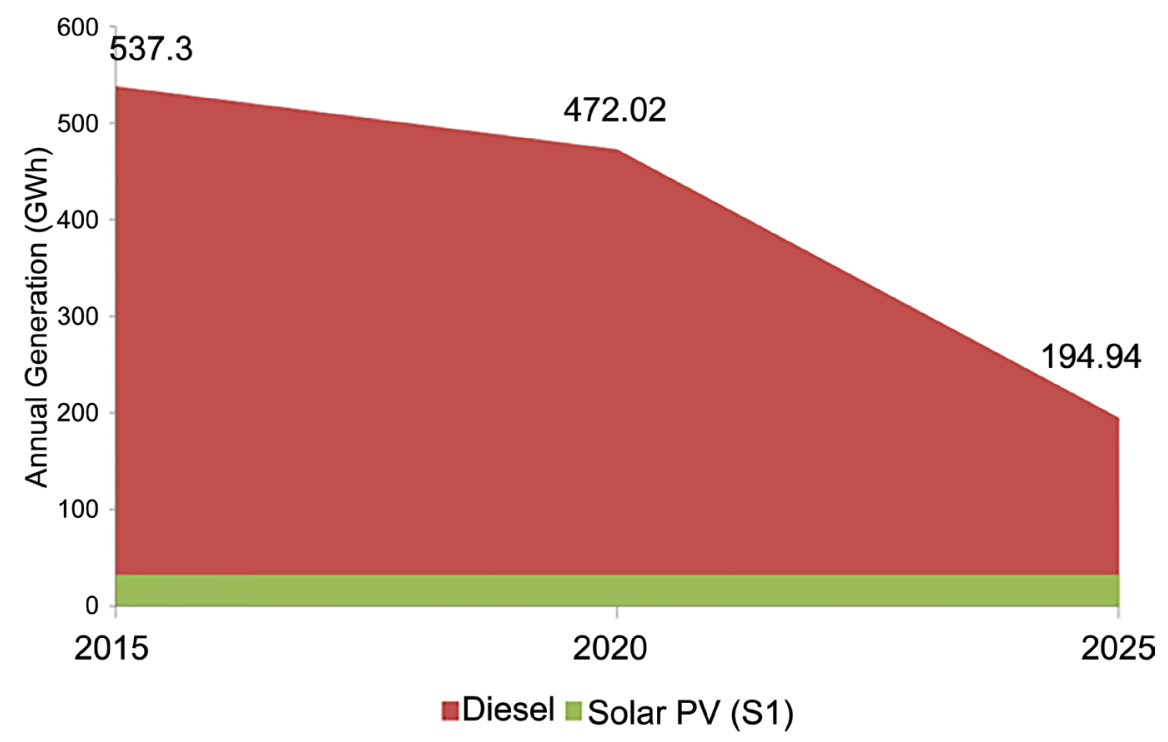

Figure 7. Sabah generation forecast for diesel power plants.

ple payback for each proposed solar PV plant. From the financial analysis, it can also be found the average of $9.8 \%$ IRR was observed. From the proposed large scale plants the shortest payback period noted was 10 years as shown in Figure 8 and Figure 9. A proposed 5MW solar PV plant was calculated will take 9 years for the cash flow to equal the total investment as stimulated in Figure 9.

\section{3. $\mathrm{CO}_{2}$ Emission Mitigation}

Fossil fuel power generation has a high $\mathrm{CO}_{2}$ emission especially those from oil combustions. The application of the renewable energy such as solar power plant can reduce the greenhouse gas emission such as $\mathrm{CO}_{2}, \mathrm{CH}_{4}$ and $\mathrm{N}_{2} \mathrm{O}$. Althought here is a plan of reduction in diesel power plants in Sabah, the current existing plants may contribute an amount of $\mathrm{CO}_{2}$ therefore by replacing these diesel 


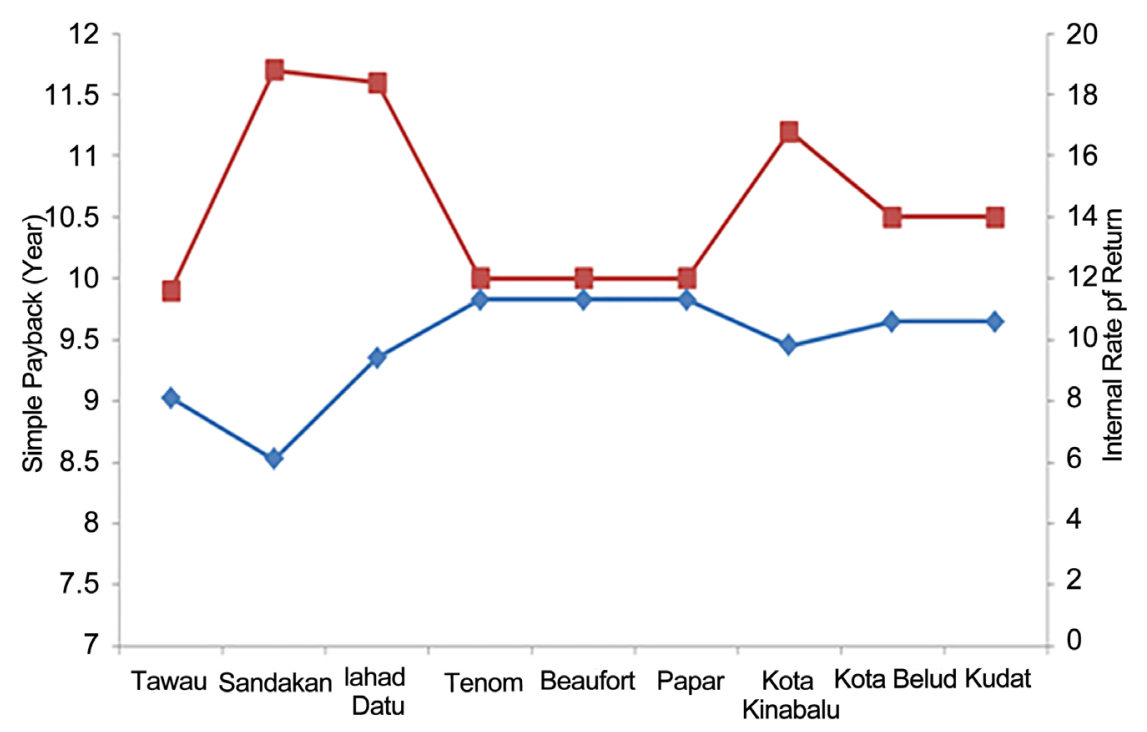

Figure 8. IRR and Simple payback analysis.

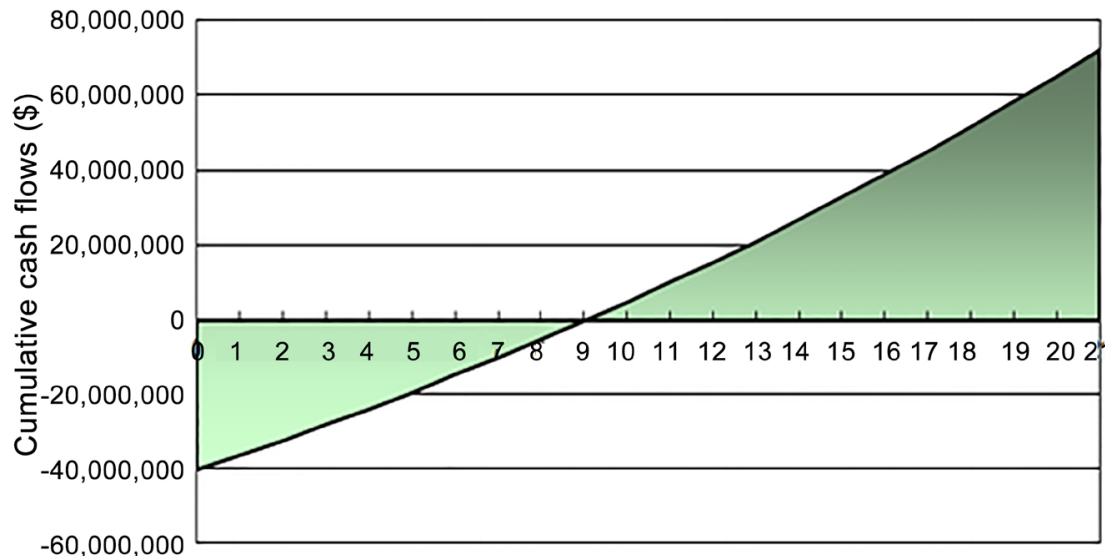

Figure 9. Cumulative cash flows in a $5 \mathrm{MW}$ solar PV plant in Sabah (Malaysian Ringgit $\mathrm{RM})$.

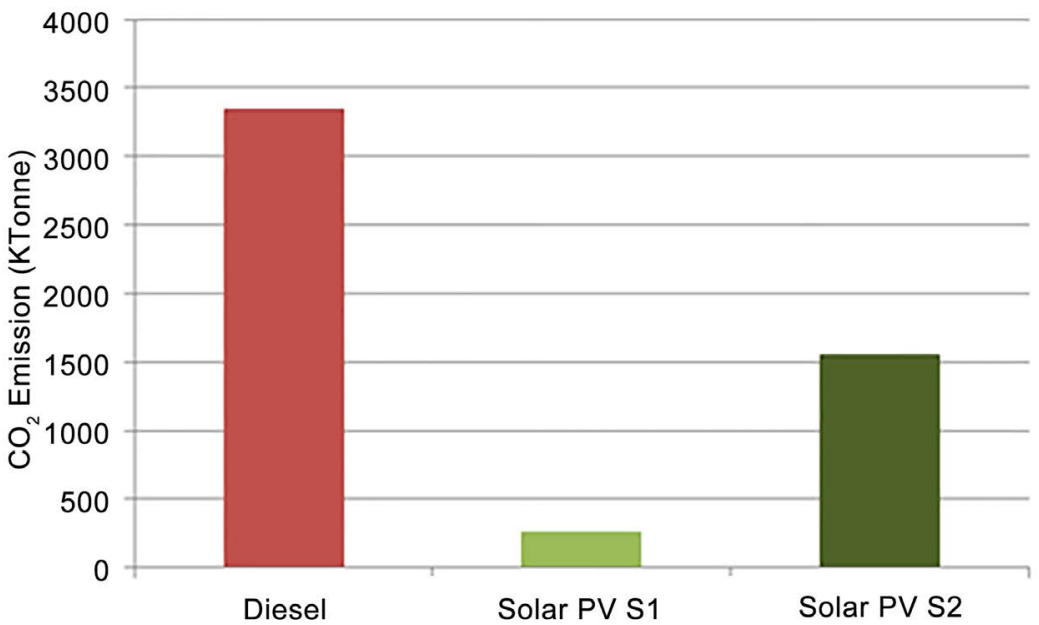

Figure 10. Projected $\mathrm{CO}_{2}$ emissions from diesel and the amount of $\mathrm{CO}_{2}$ mitigated by proposed solar PV plants in Sabah over 10 years. 
plants with large scale solar PV emission mitigation can be achieved. As shown in Figure 10, in Scenario 1 where one solar PV plant with capacity of $5 \mathrm{MW}$ electricity generation, annually this can reduce the $\mathrm{CO}_{2}$ emission from the diesel plant for $260 \mathrm{kT} \mathrm{CO}_{2}$. On the other hand in Scenario 2 where all the electricity generation from diesel power plants in another 10 years be replaced by Solar PV plants, the amount of $\mathrm{CO}_{2}$ emission avoided is $1.55 \mathrm{GT} \mathrm{CO}_{2}$.

\section{Conclusion}

This study examines the technical and economic potential of solarphotovoltaicgrid connected system in Sabah, Malaysia. The current policy of the feed in tariff is included in the study. This study investigates potential locations for 5 MW solar power plant with grid connected to fill up the peak load demand with objective to replace diesel power plants all over Sabah. Two scenarios were introduced to observe capability of one single $5 \mathrm{MW}$ plant and another scenario with number of plants to replace the diesel generation plants in the next 10 years. This study found that for the selected locations, the proposed system can generate electricity annually with average of $8.377 \mathrm{GWh} /$ year. From the financial analysis, it can also be found the average of $9.8 \%$ IRR was observed. From the proposed large scale plants, the shortest payback period noted was 10 years. With 21 years project lifetime, this shows that the application of Solar photovoltaic for gridconnected system is quite feasible financially. From the environmental aspect, this proposed system also proves that it can reduce the $\mathrm{CO}_{2}$ emission at least 260 kT CO 2 in Scenario 1 and an amount of $1.55 \mathrm{GT} \mathrm{CO}_{2}$ mitigated for Scenario 2. Based on the technical, economic and environmental indicator, it can be seen that the application of the proposed system is quite feasible to supplement the electricity grid and supply electricity when the load demand is in peak period. In order to promote developments in RE installations, the government may introduce investment incentives due to high initial cost of the solar plant installation.

\section{References}

[1] Eleventh Malaysia Plan. Chapter 6: Pursuing Green Growth for Sustainability and Resilience (2016-2020).

[2] Tenth Malaysia Plan. Chapter 6: Sustainable Energy Development (2006-2010).

[3] National Energy Balance 2015 SuruhanjayaTenaga (Energy Commission).

[4] Sabah Electricity Supply Industry Outlook 2015, (Energy Commission).

[5] Wong, S.L., Ngadi, N., Abdullah, T.A.T. and Inuwa, I.M. (2015) Recent Advances of Feed-In Tariff in Malaysia. Renewable and Sustainable Energy Reviews, 41, 42-52. https://doi.org/10.1016/j.rser.2014.08.006

[6] Sustainable Energy Development Authority Malaysia (SEDA). http://seda.gov.my/

[7] RETScreen International. Clean Energy Project Analysis: RETScreen Engineering and Cases Textbook. Minister of Natural Resource, Canada.

[8] Surface Meteorology and Solar Energy. NASA Renewable Energy Resource Website. http://eosweb.larc.nasa.gov

[9] Mekhilef, S., Safari, A., Mustaffaa, W.E.S., Saidur, R., Omar, R. and Younis, M.A.A. (2012) Solar Energy in Malaysia: Current State and Prospects. Renewable and Sus- 
tainable Energy Reviews, 16, 386-396. https://doi.org/10.1016/j.rser.2011.08.003

[10] Pauzi, M., Kassim, M., Al-Obaidi, K.M., Arkam, M. and Munaaim, C. and Mokhti Salleh, Abd. (2015) Feasibility Study on Solar Power Plant Utility Grid under Malaysia Feed-In Tariff. American Journal of Engineering and Applied Sciences, 8, 210-222. https://doi.org/10.3844/ajeassp.2015.210.222

Submit or recommend next manuscript to SCIRP and we will provide best service for you:

Accepting pre-submission inquiries through Email, Facebook, LinkedIn, Twitter, etc. A wide selection of journals (inclusive of 9 subjects, more than 200 journals)

Providing 24-hour high-quality service

User-friendly online submission system

Fair and swift peer-review system

Efficient typesetting and proofreading procedure

Display of the result of downloads and visits, as well as the number of cited articles Maximum dissemination of your research work

Submit your manuscript at: http://papersubmission.scirp.org/

Or contact epe@scirp.org 